is $-\frac{1}{53}$. The latest value of the mass resulting from theory is that given by Leverrier (Annales, vol. xi. p. 3), viz., $\frac{1}{251250}$.

Prof. Hall compares his elements with the observations made at other observatories, of which those of Cambridge, U.S., Glasgow, U.S., Pulkowa, and Mr. A. Common, of Ealing, were the most successful. The magnitudes of the satellites, free from the glare of the planet, were estimated at about 12 and $11 \frac{1}{2}$, Phobos being the brighter of the two. On October 15 , when their distances from the centre of the planet were respectively $23^{\prime \prime}$ and $57^{\prime \prime} 5$, they were of nearly equal brightness. Prof. Hall further remarks: "The chief difficulty of observing these satellites is on account of the brilliancy of the planet. At their elongations at opposition in 1877 , they appeared to me brighter than the outer satellites of Uranus and much brighter than Hyperion, and on October $3 \mathrm{I}$ Deimos resembled Umbriel, the second satellite of Uranus, which, at elongation, is fainter, I think, than any other satellite."

With the angular values of the mean distances given above, the real distances of the satellites from the centre of their primary will be for Phobos, 5,800, and for Deimos, I 4, 500 miles ; the former, from the rapidity of its motion (it performs more than three revolutions in the Martian day) will appear to rise in the west, meeting and passing the outer moon, and setting in the east, and it will have a horizontal parallax amounting to $2 \mathrm{I}^{\circ}$.

Prof. Hall has definitively adopted the names proposed by Mr. Madan, of Eton, in the columns of NATURE.

The Saturnian Satellite, Titan.-The following are the approximate times of conjunction of the great satellite of Saturn, with the perpendicular to the plane of the ring, during the next month, at which times occultations by the planet, or transits over its disc take place. The elements used are very nearly those of Bessel, but with a somewhat larger ellipticity of the planet.

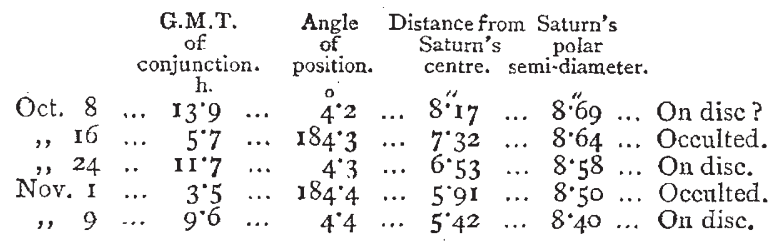

\section{WINGLESS INSECTS OF THE FALKLAND ISLANDS}

WILST on an excursion to Port Darwin, in the Falkland Islands, during the visit of H.M.S. Challenger to that group, I found at Darwin Harbour, Choiseul Sound, some insects which are of considerable interest, since, as I believe, they are closely allied to those of Kerguelen's Land. Amongst them were a gnat, practically wingless (Tipulidæ), and a fy with rudimentary wings. The gnats were found crawling on the rocks on the sea-shore, in sheltered places, and also on the sunny, sheltered side of a fence composed of a peat bank, with furze growing on the top of it. They run quickly, and, when in danger, draw up their legs and drop in order to escape, and they are not by any means easy to catch amongst the grass.

The flies were found only on the sea-coast, in hollows under overhanging slabs of the sandstone rocks, sheltering themselves in crevices. They have short wings, which they seem to use in jumping, and they spring nimbly, like fleas or small grasshoppers, and are difficult to catch. On comparing specimens of these flies with specimens of Amalopteryx maritima, one of the flies of Kerguelen's Land, with rudimentary wings, described by Mr. Eaton (Rev. E. A. Eaton, the Entomologist's Monthly Magasine, August, I875), I have little doubt that they are very closely allied to this species, and to be referred at least to the same genus. Dr. Kidder describes the habits of the Kerguelen Amalopteryx as closely similar (J. H. Kidder, M.D., Bulletin United States National Museum, No. 3, 1876, ii. p. 52). Von Willemoes Suhm found a species of the same genus in Marion Island, and we all observed the fly at Kerguelen's Land as well as the wingless gnat which $\mathrm{Mr}$. Eaton has named Halyritus amphibius, and which lives on the Kerguelen sea-shore amongst sea-weed constantly wetted by the tide. It would be interesting if the Falkland Island gnat proved allied to the Kerguelen one on further examination.

I found one beetle with wings at the same locality in the Falklands, and one wingless species. All the Kerguelen beetles are wingless. Two genera and all the species of that island are endemic (Mr. C. O. Waterhouse, Entomologist's Monthly Magazine, August, 1875 , p. 50). The close connection between the Fuegian flora and that of the far distant Kerguelen's Land is well known from the investigations of Sir Joseph Hooker. It is interesting to find a further connection in the insects. The four wingless flies of Kerguelen's Land are assigned by Mr. Eaton to four new genera. I believe, though I am no entomologist, that the Falkland Island and Marion Island fly will come under one of these, and possibly further search may prove the existence of representatives of some of the other genera in Fuegia or the Falklands. I see from the "Histoire Nat. des Insectes Diptères". of the Suitesa Buffon, the only authority immediately at hand, that a wingless gnat, Chionea araneoides, is found in Sweden in woods on the snow throughout the winter, whilst two flies with rudimentary wings, Apterina pedes. tris of France and Germany, and Myrmemorpha brachyptera of Spain, exist in Europe. These merely as examples. Prof. Westwood tells me many other such diptera are known to entomologists, and he has shown me a specimen of a wingless fly, Borborus apterus, which occurs in England.

Exeter College, Oxford

H. N. MOSELEY

\section{SUN AND EARTH}

THE Meteorological Reporter of the Bombay Presidency, Mr. F. Chambers, at the end of his recentlypublished report for $1877-78$ gives us the first results of some important researches which he has not yet been able to complete, owing to want of clerical assistance. In a brief sketch of the meteorology of the Bombay Presidency in 1876 prepared for the Bombay Administration Report for $1876-77$, he showed that the abnormal meteorological conditions which produced the famine of 1877 were of the same type as those which produce the usual alternations of seasons, and therefore are attributable to similar causes.

A commencement was made some time ago with the discussion of the Kurrachee wind observations. One of the most important results already obtained is that the numerical relation existing between the abnormal wind and abnormal barometric movements is exactly similar to the relation between the annual variations of the wind and barometer leading to the same conclusion as above, viz., that most of the abnormal variations of weather in India are due to causes which are similar to, if not identical with, those which produce the normal variations. The comparison of the normal and abnormal barometric movements at different stations points decidedly in the same direction, and Mr. Chambers believes that further investigation will prove this to be a general law, affecting perhaps all abnormal meteorological variations which are not cyclonic. He adds :-

"The fact that a famine has been raging in China, at the same time that one has ravaged Southern India, does not appear to be without its significance, in pointing to 
other than local causes of the metcorological disturbances which produce famines. Indeed, the inference that most of the unusual variations of weather in tropical climates are incluced by corresponding variations in the absolute heating power of the sun, in the same manner that the seasonal variations arc induced by those changes of heating power which depend on the relative motions of that body, secms almost irresistible, if it may not be regarded as already partly proved. The importance of this conclusion, if true, will be readily admitted, for it will be at once apparent, that if the absolute variations of the sun's heat are fitful in their occurrence, and do not obey definite periodical laws, it will perhaps never be possible to predict by more than a few days in advance the unseasonal variations of weather induced by them, while if such laws can only be discovered, the possibility of our being able to predict their consequences is equally certain."

\section{OCCURRENCE OF FOSSILIFEROUS TER- AND GEORGE'S BANK}

A MONG the most important results of the investigations made by the party connected with the United States Fish Commission, stationed at Gloucester, Mass., during the present season, is the discovery of fragments of a hitherto unknown geological formation, apparently of great extent, belonging probably to the miocene or later tertiary. The evidence consists of numerous large fragments of eroded, but hard, compact, calcareous sardstone and arenaceous limestone, usually perforated by the burrows of Saxicava rugosa, and containing in more or less abundance fossil shells, fragments of lignite, and in one case a spatangoid sea-urchin. Probably nearly one-half of the species are northern forms, still living on the New England coast, while many others are unknown upon our coasts, and are apparently, for the most part, extinct. From George's Bank about a dozen fossiliferous fragments have been obtained, containing more than twenty-five distinct species of shells. Among these one of the most abundant is a large thick bivalve (Isocardia) much resembling Cyprina islandica in form, but differing in the structure of the hinge. This is not known living. My'a truncata, Ensatella Americana, and the genuine Cyprina are also common, together with a large Natica, a Cyclocurdic (or Ventericardia) allied to C. borealis (Con.), but with smaller ribs, Cardium islandicum, and also various other less common forms. These fragments came from various parts of the bank, including the central part, in depths varying from 35 to 70 fathoms, or more.

From Banquereau, N. S., we received one specimen of similar rock, containing abundant fragments of a large bivalve, and about a dozen other species, among which are Fiusus (Chrysodomutus) deccincostatus, Latirus albus, Jeff. (?), unknown species of Turritella, \&c. From the Grand Bank two similar specimens were received. Cne of these, flom thirty-five fathoms, lat. $44^{\circ} 30^{\prime}$, long. $50^{\circ} 15^{\prime}$, contained numerous specimens of Cyprina islandica in good preservation.

In gathering these specimens from the fishermen and working out the specimens Mr. W. Upham has been very active. It will probably be possible hereafter, when these specimens shall have been more fully examined, and more obtained, to give a pretty long list of species, cspecially from George's Bank.

At present it appears probable that thesc fragments have becn detached from a very extensive submerged tertiary formation, at least scveral hundreds of miles in length, extending along the outer banks, from off $\mathrm{New}$ foundland nearly to Cape Cod, and perhaps constituting, in large part, the solid foundations of these remarkable submarine elevations.

\section{THE BALLOON EXPERIMENTS AT WOOLIVICH}

THE military ballonn experiments at Woolwich have been so far successful, that last week an aëronaut was lifted some 700 fect, to a height, therefore, sufficient for reconnoitring purposes. There is nothing of novelty in this, as a matter of aërial navigation, although it is the first instance, we believe, of any one in this country being raiscd from the earth by the agency of pure hydrogen, but it is, nevertheless, something to have achieved in the circumstances under which Capt. 'Templar has been working. Everybody knows that hydrogen is gifted with extraordinary lifting power, just as every chemist is aware that the gas inay be produced in the way Capt. Templar produced it, namely, by passing a jet of steam over iron turnings. But the problem under solution was not to send up a hydrogen balloon so much as to discover whether the thing could be done in a haphazard fashion, and with such simple means as an army in the field would be provided with. It is one thing to make hydrogen in the laboratory, and another to make a sufficient supply of it just whenever the commander of an army may order a balloon reconnaissance to be made.

Capt. Templar bas practically proved that this can be done. He requires a supply of steam, an improvised furnace of some sort, and a tube filled with iron turnings; given these, he can provide hydrogen sufficient to lift a scout high into the air. The tube at present employed by Capt. Templar is six or eight inches in diameter, and some half-dozen feet long; it is filled loosely with iron turnings and placed in a furnace where it becomes red hot. Steam is now passed through the tube, and hydroe gen issues forth, the oxygen from the decomposed steanz going to form ferrous oxide. So completely do the iron turnings do their work under these circumstances, that not only is the surface of the metal acted upon, but it is oxidised well-nigh throughout.

Naturally enough, the hydrogen comes away with a good deal of vapour, and, if pure gas is desired, some desiccating arrangement will have to be employed; but. so far Capt. Templar has used none. His balloon, which. is of lawn, dressed with boiled oil and glue, will contain about 10,000 cubic fect, but last week not more than 9,000 feet of hydrogen was introduced. The gas was. generated from the tube at the rate of something like

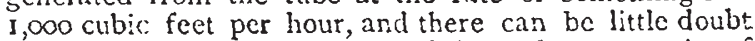
that, during the long period of filling, a large quantity of the vapour that was mixed with the hydrogen condensed, and ran out of the balloon in the form of water. Pure hydrogen should have a lifting power of $70 \mathrm{lb}$. per 1,000 feet, or perbaps a little more, but it is hardly likely that gas produced in a rough-and-ready fashion in the freld will possess this degrec of buoyancy. Still, Capt. Templar was successful in lifting balloon, aerronaut, ballast, and 700 feet of rope- for the ascent was a captive one--by means of 9,000 cubic feet of hydrogen, prepared in the way we have mentioned.

Another point is worthy of note in connection with the experiment. The fabric of the balloon kept the hydrogen imprisoned for a much longer period than had been anticipated. A dozen hours scarcely impaired the buoyancy of the balloon, and by adding yet anotber waterproof coating it is anticipated that the balloon will remain inflated for four-and-twenty hours.

The next step will be to discover how far it is possible to compress hydrogen so manufactured into cylinders for conveyance in transport waggons, so that a supply of hydrogen may be at hand whencver an ascent is determined upon in the field. Capt. Templar is sanguine of compressing the gas to a fourth of its volume, and thus decreasing its bulk considerably, when she balloon-train is on the march. How far this is practicable experiment only can prove. 